\title{
Impact of ecological landscape changes toward community life in Southern Malang during the $19^{\text {th }}-20^{\text {th }}$ Century
}

\author{
L. Ayundasari*, J. Sayono \& S.D. Utari \\ Universitas Negeri Malang, Malang, Indonesia
}

\begin{abstract}
Southeast Malang is one of the most dynamic areas in Malang in the 19th-20th century. This is due to the fundamental socio-economic changes from a subsistence society to an industrial society and into a working-class society. This research aims to explore the impact of environmental changes on the patterns of community life that occur there. The locations of this research are Dampit, Tirtoyudo, and Ampelgading. The research method used was historical. Data was collected through interviews, field observations, and documentation. The study results indicate the presence of social changes caused by ecological transformation as an indirect impact of dozens of private coffee plantations in this region.
\end{abstract}

Keywords: ecological landscape, environmental changes, Southern Malang

\section{INTRODUCTION}

Life is a dynamic process and change is a certainty, including economic field. One of the figures who studied economic change was Rostow who stated that the stages of economic development consisted of 5 phases, namely: The Traditional Society, The Preconditions for Take-off, Takeoff, The Drive to Maturity, and The Age of High Mass Consumption (Rostow 1960). Economic development supported by advances in technology and investment have had a major impact on social, cultural and environmental changes such as what happened to traditional communities in remote areas in Kalimantan, Sumatra and Papua. (Petrenko et al. 2016; Hidayah et al. 2016; Pirard, et al. 2017; Imadudin 2014). A similar phenomenon also occurs in developed countries and other developing countries such as Spain, Bangladesh and Ethiopia (Watson et al. 2014; Ghosh et al. 2020; Nigussie et al. 2021). These events have a similar pattern to the development of a plantation technology-based economy in Indonesia in the 19th century.

Economic liberalism, which was marked by the freedom of foreign investment and the development of large industries, occurred in Indonesia towards the end of the 19th century - during the enactment of the liberal economic system established by the Dutch East Indies Government. At this time, liberalism was not just an invitation but took the form of a policy by giving permits to foreign private companies to invest in cash crops such as coffee, rubber, quinine, tea, sugar cane, and others (Kadir 2018). In terms of Rostow's theory of economic development, at that time, Indonesia was classified in the category of a take-off society because it had entered the industrial sector with a high growth rate, along with an established political, social and institutional framework. However, Indonesia was only a colony whose economic and political stability depended on the mother country. In addition, the Indonesian people's position was only as plantation workers or factory employees (Hudiyanto 2015).

A series of significant depression-era events, World War II, the Japanese occupation and the independence revolution, all resulted in the beginning of the collapse of Indonesia's plantation industry. This occured throughout the region, including in the former Afdeeling Malang in Malang's

\footnotetext{
*Corresponding author: lutfiah.fis@um.ac.id
} 
coffee plantation centers of Dampit and Ampelgading. The two districts that had been successful in coffee production for almost 50 years were slowly dying out. This is due to many factors, including the international failure of plantation products due to war, the absence of a support system for the plantation product care and processing, such as Mantri who usually handle and provide counseling, and the insufficient attention of the new government to the plantation industry. During the Old Order and New Order governments, this region was marginalized. The low level of welfare caused the new generation in this region to choose to work abroad. Until now, this area has been known as a migrant worker enclave. Therefore, this study aims to find out details about the effects of changes in the ecological landscape as a result of economic development on the community life pattern changes in Southeast Malang in the 19th-20th centuries.

\section{METHODS}

The method used in this study was a historical research method, which consists of four stages: heuristics, criticism, interpretation, and historiography (Kuntowijoyo 2005). Historical sources used in this study consisted of two types, namely primary and secondary. The primary source of this research was the archives on plantations in Ampelgading and Dampit. Meanwhile, secondary sources were obtained from reports and interviews with historical actors. Observation activities were carried out by following evidence of change in the ecological landscape during the period of large plantations, such as coffee plantations, factories and water management for coffee production. All the collected data was analyzed for its validity through internal and external criticism processes. The next stage was the interpretation, which consisted of interpreting and analyzing data using sociological and economical lenses so that the historical narrative presented in narrative form fully described the phenomenon. The final stage of this research was historiographical, consisting of the examination of of changes in the ecological landscape on the people's patterns of life in Southeast Malang in the 19th century.

\section{RESULTS AND DISCUSSION}

\subsection{Geographical and administrative conditions of Southeast Malang}

Southeast Malang is a term deliberately used to refer to three sub-districts, namely Dampit, Tirtoyudo, and Ampelgading. This term was developed to make it easier to refer to the region. The three districts are geographically located on the slopes of Mount Semeru, with land contours consisting of valleys, slopes and hills. There are two types of soil that dominate this area, namely latosol reddish-brown and mediteran reddish brown. The land is famous for being fertile and very suitable for use as agricultural and plantation land. This was the main motivation for the large-scale clearing of plantation land by the Dutch government in the 19th century, both by the private and Dutch colonial governments. Apart from fertile land, this region also has an abundant supply of water due to the dense forest nearby. One of the upstream rivers in this area is the Lesti River. Besides that, there are also dozens of water sources that are spread across the three sub-districts.

The perfect mix of soil types and water sources in Southeast Malang has invited many newcomers to settle in this region. However, before the big plantation era in the mid-19th century, this area did not have many inhabitants for several reasons, including the contours of the hilly land that limited access, most of which were still wild and needed further processing. In addition, there were no production plants to be used for the fulfillment of living needs. The remoteness of this area led to there being no practical modes of transportation. Apart from this, East Java's population distribution until the beginning of the 19th century was not evenly distributed and remains as dense as it is today. At that time, the population distribution was still concentrated in the city centers of the trading route on Java's north coast. Meanwhile, mountainous areas, especially in the interior of the southern part of Java, were still mostly uninhabited and took the form of forests. 
The distribution of population towards Southeast Malang is inseparable from the development of Malang as afdeeling and gemeente. Afdeeling was one of the Dutch colonial government structure levels, which was equivalent to a district. Structurally, Afdeeling's position was part of the residency, whose leader was referred to as the assistant resident. One residency often consisted of several afdeelings. Meanwhile, gemeente was the name of an administrative division in a state structure equivalent to a municipality. Afdeeling Malang consisted of five controllers, namely Malang City, Batu, Kepanjen, Turen and Tumpang. Southeastern Malang was under the Turen district administration, which consisted of Turen, Wajak, Dampit, Ampelgading and Sumbermanjing. Administratively Afdeeling Malang was included in the Pasuruan Residency, which borders Surabaya, Kediri and Probolinggo.

\subsection{Changes in landscape in Southeast Malang, $19^{\text {th }}-20^{\text {th }}$ Century}

Southeastern Malang was administratively under Afdeeling Malang. The rapid development in this area occurred after the enactment of the Agrarian Law of 1870. A law born because of liberals in the Netherlands allowed private parties to play a role in land management in the Dutch East Indies and have erfpacht rights. Foreign investors could lease land for 75 years from bumiputera, and on average, the land was planted with industrial crops such as tea, coffee, sugarcane, cacao, quinine, cloves, indigo, and so forth. The enactment of this law had a major impact on the social and economic life in Java and Sumatra island. These impacts include monetization in Java, the growth of the plantation sector in South Bandung, the limited economic activity of Arabs in Surabaya (Utami 2015; Jayanto 2016; Hakim 2018). Meanwhile, in Malang, the enactment of this law impacted the mushrooming of private plantations, especially in Dampit and Ampelgading. Based on the Ampelgading map around the early 19th century, there were many cultivated plantations in this area such as $O g$ Soemberandong, Og Kaliglidik, Og Lebakroto, Og Soemberremis, Og Wonokojo, Og Soembersengkaring, Og Soembertelogo, Og Soembertjeleng, Og Sonosekar, OG Sonowangi, and so forth.

The existence of this cultivation plantation (onderneming) has influenced the changes in the landscape and life patterns in Southeast Malang. There was a large-scale change of land use as a result, initially changing the wilderness into production plant land. In addition, the existence of these plantations invited the presence of people outside Southeastern Malang to settle there. Seeing Southeastern Malang's potential, the colonial government built transportation access to facilitate the transportation of agricultural products, among others, by making an axle road that could be traversed by cars from Malang to Ampelgading. In addition, a tram line was also built connecting Malang-Dampit as a continuation of the Lawang-Malang railway line, which was completed in 1879 (Handinoto 2004).

The conversion of land functions in the Southeast Malang region is an important marker for socio-economic changes in this region. The land is one of the natural resources that has significant benefits and functions in life because it is used for various things such as shelter and livelihood. Land often changes from time to time, according to how its used. Since the mid-19th century, there has been an increase in land use to cultivate various plantation products such as tea, coffee, sugarcane, quinine, cocoa, indigo and others. Accelerated due to European market demand, this phenomenon increased rapidly with the enactment of the Liberal Law, which allowed private parties to participate in the plantation industry. This activity changed the function of land in most of the islands of Java and Sumatra. In the afdeeling Malang, the visible changes are from forest land to plantation. Along with the rapid and almost total plantation coverage in Southeastern Malang, this certainly affected population growth. This population growth occurred due to migration from several areas outside Afdeeling Malang. This population displacement is caused by various things such as disease outbreaks, lack of employment opportunities, and the desire to improve living standards. Some of these reasons encourage population movement from one area to another. The migration that occurs in Afdeeling Malang was influenced by economic factors (Sayono et al. 2020). This can be seen from a large number of residents outside the area who have moved to work in the plantation sector as loggers to prepare the land, plant seeds, create plant nurseries 
and harvest plantations. Apart from plantation activities, the presence of these migrants was also influenced by the existence of plantation product processing factories in Southeast Malang and its surroundings, such as the Margosuko Coffee Factory, Wonokoyo Coffee Factory, Krebet Sugar Factory, Kebonagung Sugar Factory, et cetera.

Landscape changes in the Southeast Malang region are also affected by residential patterns. Prior to the 19th century, the settlement patterns in Southeast Malang were sporadically scattered around crowds such as markets and main roads. It was rare for the population to live near the highest slopes. However, the presence of plantations and processing industriesd caused settlement patterns to change. This change is especially evident in the Ampelgading area, where there are dozens of private ondernemings starting from Kaliglidik (the last village that is near the peak of Semeru) to Lebakroto, which is on the Malang-Lumajang axis. This settlement pattern is in the form of clusters of houses around big factories which are called kampungan, and special shelters in plantation complexes known as persil. The existence of these plantations and factories has changed the physical patterns of settlement and the composition of the population. Today, in Southeast Malang, we often find large families of the Madurese tribe who have lived for generations. They are mostly the fourth or fifth descendants of their ancestors who migrated to the region around the early 19th century. Based on the data collected by Gooszen about immigration in Afdeeling Malang, the largest population of migrants to this area are Madurese, then Javanese from various regions, especially Karesidenan Kediri and the Central Java region (Gooszen 1999). In addition, there are some Chinese ethnic migrants whose numbers can be counted on one hand. In Ampelgading, a family who are the fourth descendants of the Mbok Denok family can be found. They are Chinese people who traded in Pasar Jagalan, then married local residents and settled there. The number of ethnic Chinese people is more common in Dampit, especially around markets. Most of these ethnic groups work as collectors and distributors in the coffee trade.

\subsection{The effect of landscape changes on the life patterns of the Southeast Malang Community in the $19^{\text {th }}-20^{\text {th }}$ Century}

Changes in landscape and settlement patterns significantly affect the pattern of community life. This is due to the close relationship between humans and the environment. This environment's influence can be divided into two factors, namely the physical environment and the social environment. The physical environment here is the environment that covers an area's geography, while the social environment is the community environment consisting of the interactions between individuals (Walgito 1992). Additionally, changes in Indonesia's social environment after the Islamic sultanate were greatly influenced by the arrival of Europeans. This change began with trade interactions in the early 15 th century and turned into colonialism, which lasted until the mid-20th century. Each region in Indonesia has different natural resources, ranging from spices to plantation crops.

Southeast Malang has never been affected by the glory of spices. This area became known by the colonial government for its soil fertility, which was suitable for plantation commodity crops around the early 19th century. Prior to the 19th century, it could be identified that the environment of Southeast Malang was mostly forest, which had an impact on the activities of the people who, on average, made a living by utilizing forest products, and it was possible that economically they still used the barter system in fulfilling their daily needs. Meanwhile, in the second half of the 19th century, when the big plantations were established, the people became working-class people who spent much of their time as plantation and factory workers. Various types of work emerged as a result of these changes in the environment, including wiwil and gacok. Wiwil is a coffee tree cleaner, who cleans bad coffee shoots, while gacok is a job as a craftsman that cleans plant roots around the coffee tree.

The new types of work in the plantation environment also accelerate social stratification based on professions in sequence, such as large foremen, area foremen, chant foremen and laborers. Firstclass, the big foreman, is the leader of several coffee plantation areas. Second class, the foreman Isan is a foreman who leads a plantation area. The third class, the Rantek foreman, is a small foreman who oversees several groups of workers according to their classification in one plantation 
area. The last class, the workers, are a group of workers specialized based on their daily work as cleaners, cultivators, carers and harvesters. This structured work is rewarded with a monetary salary. As previously explained, in almost all large plantation areas, the community recognizes monetization earlier than other communities. In Southeast Malang, workers' salaries were paid by means of a roller system by queuing for daily wages in front of lodji. In one day, female workers earned 1 ece (one level below the cent) and male workers attained 15 cents.

This new life pattern did not last long, only about 50 years. This change in the pattern was marked by the great depression of 1930 . The crisis in America, which was preceded by the fall of Black Tuesday and the fall of the New York stock market on October 24, 1929, and reached its worst peak on October 29, 1929, had significant impacts on the world economy, including Southeast Asia (Rothemund 1996). In Southeast Asia, Java and East Sumatra were among the most affected because these two islands had large plantation industries owned by foreign investors under the Dutch colonial government's control (Siswoyo 2017). This phenomenon also occurred in Dampit and Ampelgading. Areas that were initially considered vital because they were cash crop producers had become neglected areas. This event was exacerbated by the arrival of Japan, which only focused on winning the Pacific War. Agricultural commodities whose sustainability was maintained included rice and corn to maintain food stability.

The absence of the maintenance of plantation crops in Southeast Malang caused many diseases, especially fungi that appeared on the roots, stems, and branches of crops. The events of independence and the revolutionary war resulted in resentful sentiments towards the remnants of colonialism, and great anger materialized in the form of burning plantation land, destroying facilities such as dams and water reservoirs and coffee processing factories. This further eliminated traces of the greatness of the plantation industry and cut the chain of knowledge in plantation cultivation. After the physical revolution, namely the Old Order and New Order periods, the Southeast Malang region became a region with no economic potential. This region has no uniqueness of industrial or agricultural products so that its development process is slow. In the New Order era, plantation lands left a perpetual agrarian conflict. The struggle for land use rights between Limited Liability Company Perkebunan Negara XII (PTPN XII) and the people resulted in neglecting these potential lands.

Slow changes in the ecological landscape in this area resulted in slow economic growth which led to people looking for new types of jobs that offered a better life, one of which was to travel and become a migrant worker. The people of the Southeast Malang region recognized this new profession since the early 1980s, and it was increasingly used as their main livelihood in the 1990s. Towards the end of the 20th century, the Southeast Malang region was known as the center of migrant workers. The consequence of this phenomenon is the waning popularity of agricultural work. Since then, this region's ecological landscape has not changed much because nature-based jobs such as agriculture and plantation work cannot directly bring wealth like being migrant workers in Saudi Arabia, Hong Kong, Singapore and Taiwan can.

\section{CONCLUSION}

Based on this research, the ecological changes that occured as a result of the economic development of The Take-off stage in Southeast Malang had a major impact on the pattern of its society's social and cultural lifestyle. The first ecological change was marked by the presence of industrial plantations under the domination of the colonial government, which resulted in changes of the forest landscape into industrial crops (coffee), the emergence of a new class (plantation workers) and monetization. Meanwhile, the second ecological change was marked by the destruction of coffee plantations as a result of the Great Depression and the Independence Revolution that resulted in a shift in social classes from the plantation worker communities becoming the transmigrant and migrant worker communities. This also turned out to bring a new culture like in the destination areas of migrants both domestically and abroad. 


\section{REFERENCES}

Ghosh, D. K., Hossain, M. N., Sarker, M. N. I., \& Islam, S. 2020. Effects of land-use changes pattern on tree plantation: Evidence from gher land in Bangladesh. International Journal of Agricultural Policy and Research, 8(June), 55-65.

Gooszen, H. 1999. A Demographic History of the Indonesian Archipelago, 1880-1942. Leiden: KITLV Press.

Hakim, C. 2018. Politik Pintu Terbuka: Undang-Undang Agraria dan Perkebunan Teh di Daerah Bandung Selatan 1870-1929. Ciamis: Vidya Mandiri.

Handinoto. 2004. Kebijakan Politik dan Ekonomi Pemerintah Kolonial Belanda Yang Berpengaruh Pada Morpologi (Bentuk Dan Struktur) Beberapa Kota Di Jawa. Dimensi Teknik Arsitektur, 32(01), $19-27$. Retrieved from http://fportfolio.petra.ac.id/user_files/81-005/Kebijakan Politik.pdf

Hidayah, N., Dharmawan, A. H., \& Barus, B. 2016. Ekspansi Perkebunan Kelapa Sawit Dan Perubahan Sosial Ekologi Pedesaan. Sodality: Jurnal Sosiologi Pedesaan, 4(3). https://doi.org/10.22500/sodality.v4i3.14434

Hudiyanto, R. 2015. Kopi Dan Gula: Perkebunan Di Kawasan Regentschap Malang, 1832-1942. Jurnal Sejarah Dan Budaya, 9(1), 96-115.

Imadudin, I. 2014. Dampak Kapitalisme Perkebunan terhadap Perubahan Kebudayaan Masyarakat di Kawasan Subang 1920-1930. Patanjala, 6(1), 65-80.

Iqbal, M., \& Sumaryanto. 2016. Strategi Pengendalian Alih Fungsi Lahan Pertanian Bertumpu pada Partisipasi Masyarakat. Analisis Kebijakan Pertanian, 5(2), 167-182. https://doi.org/10.21082/akp.v5n2.2007.167182

Jayanto, J. 2016. Industri Gula Di Karesidenan Cirebon Tahun 1870-1930 Dan Dampaknya Bagi Masyarakat. Ilmu Sejarah - S1, 1(1), 1-15. Retrieved from http://journal.student.uny.ac.id/ojs/index.php/ilmusejarah/article/view/4307

Kadir, H. A. 2018. Komparasi Munculnya Liberalisme Ekonomi di Indonesia dan Burma. Lembaran Sejarah, 13(2), 163. https://doi.org/10.22146/lembaran-sejarah.33541

Kuntowijoyo. 2005. Pengantar Ilmu Sejarah. Yogyakarta: Bentang.

Nigussie, Z., Tsunekawa, A., Haregeweyn, N., Tsubo, M., Adgo, E., Ayalew, Z., \& Abele, S. 2021. The impacts of Acacia decurrens plantations on livelihoods in rural Ethiopia. Land Use Policy, 100 (July 2020). https://doi.org/10.1016/j.landusepol.2020.104928

Petrenko, C., Paltseva, J., \& Searle, S. 2016. Ecological impacts of palm oil expansion in Indonesia. White Pater, (July), 1-21. Retrieved from http://www.theicct.org/ecological-impacts-of-palm-oil-expansion-indonesia

Pirard, R., Petit, H., \& Baral, H. 2017. Local impacts of industrial tree plantations: An empirical analysis in Indonesia across plantation types. Land Use Policy, 60, 242-253. https://doi.org/10.1016/j. landusepol.2016.10.038

Rostow, W. W. 1960. The Stages of Economic Growth. In Political Studies (Vol. 10). https://doi.org/ 10.1111/j.1467-9248.1962.tb00978.x

Rothemund, D. 1996. The Global Impact of the Great Depression 1929-1939. New York: Taylor and Francis.

Rustiadi, E. 2001. Alih Fungsi Lahan dalam Perspektif Lingkungan Perdesaan. Lokakarya Penyusunann Kebijakan Dan Strategi Pengelolaan Lingkungan Kawasan Perdesaan, 10-11 Mei(November).

Sayono, J., Ayundasari, L., Ridhoi, R., \& Irawan, L. Y. 2020. Socio-economic impact in-out migration phenomenon in Southeastern Malang in 19th-20th. IOP Conference Series: Earth and Environmental Science, 485(1). https://doi.org/10.1088/1755-1315/485/1/012023

Siswoyo, T. 2017. Pengaruh Malaise terhadap Perkebunan Kolonial Di Hindia Belanda Tahun 1930-1940. Lampung: FKIP Universitas Lampung.

Utami, I. W. P. (2015). Monetisasi Dan Perubahan Sosial Ekonomi Masyarakat Jawa Abad XIX. Jurnal Sejarah Dan Budaya, 9(1), 51-63.

Walgito, B. 1992. Pengantar Psikologi Umum. Yogyakarta: Andi.

Watson, S. J., Luck, G. W., Spooner, P. G., \& Watson, D. M. 2014. Land-use change: Incorporating the frequency, sequence, time span, and magnitude of changes into ecological research. Frontiers in Ecology and the Environment, 12(4), 241-249. https://doi.org/10.1890/130097 